\title{
The Social Preferences of
}

Democratically Elected

Decision Makers and the

Conflict Between Wealth

\section{Generation and Distribution}

ALEXIA GAUDEUL

CLAUDIA KESER 
2017s-25

\title{
The social preferences of democratically elected decision makers and the conflict between wealth generation and distribution
}

\author{
Alexia Gaudeul, Claudia Keser
}

\begin{tabular}{c}
\hline Série Scientifique \\
Scientific Series
\end{tabular}

\section{Montréal}

Novembre/November 2017

(C) 2017 Alexia Gaudeul, Claudia Keser. Tous droits réservés. All rights reserved. Reproduction partielle permise avec citation du document source, incluant la notice ${ }^{(}$. Short sections may be quoted without explicit permission, if full credit, including $\left({ }^{\circ}\right.$ notice, is given to the source.

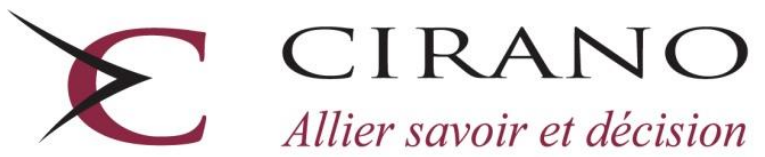

Centre interuniversitaire de recherche en analyse des organisations 


\section{CIRANO}

Le CIRANO est un organisme sans but lucratif constitué en vertu de la Loi des compagnies du Québec. Le financement de son infrastructure et de ses activités de recherche provient des cotisations de ses organisations-membres, d'une subvention d'infrastructure du gouvernement du Québec, de même que des subventions et mandats obtenus par ses équipes de recherche.

CIRANO is a private non-profit organization incorporated under the Quebec Companies Act. Its infrastructure and research activities are funded through fees paid by member organizations, an infrastructure grant from the government of Quebec, and grants and research mandates obtained by its research teams.

\section{Les partenaires du CIRANO}

\section{Partenaires corporatifs}

Autorité des marchés financiers

Banque de développement du Canada

Banque du Canada

Banque Laurentienne du Canada

Banque Nationale du Canada

Bell Canada

BMO Groupe financier

Caisse de dépôt et placement du Québec

Fédération des caisses Desjardins du Québec

Gaz Métro

Hydro-Québec

Innovation, Sciences et Développement économique

Intact

Investissements PSP

Ministère de l'Économie, de la Science et de l'Innovation

Ministère des Finances du Québec

Power Corporation du Canada

Rio Tinto

Ville de Montréal

\section{Partenaires universitaires}

École de technologie supérieure (ÉTS)

HEC Montréal

Institut national de la recherche scientifique (INRS)

McGill University

Polytechnique Montréal

Université Concordia

Université de Montréal

Université de Sherbrooke

Université du Québec

Université du Québec à Montréal

Université Laval

Le CIRANO collabore avec de nombreux centres et chaires de recherche universitaires dont on peut consulter la liste sur son site web.

Les cahiers de la série scientifique (CS) visent à rendre accessibles des résultats de recherche effectuée au CIRANO afin de susciter échanges et commentaires. Ces cahiers sont écrits dans le style des publications scientifiques. Les idées et les opinions émises sont sous l'unique responsabilité des auteurs et ne représentent pas nécessairement les positions du CIRANO ou de ses partenaires.

This paper presents research carried out at CIRANO and aims at encouraging discussion and comment. The observations and viewpoints expressed are the sole responsibility of the authors. They do not necessarily represent positions of CIRANO or its partners.

ISSN 2292-0838 (en ligne) 


\title{
The social preferences of democratically elected decision makers and the conflict between wealth generation and distribution*
}

\author{
Alexia Gaudeult, Claudia Keser
}

\begin{abstract}
Résumé/Abstract
We run a laboratory experiment where some participants are selected to make investment decisions on behalf of others. We test whether a democratic context influences the social preferences of decision makers in terms of efficiency, altruism and concern for inequality. We find that decision makers who are selected democratically are generally more efficiency-oriented, but also more altruistic, than leaders who are selected at random or by ability. Because wealth generation and distribution sometime conflict, efficiency is no higher with democratic leaders, although payoffs are more equal. We interpret our results in terms of a democratic norm that mitigates how elections may otherwise lead to an enhanced feeling of entitlement to one's role. We exclude a selection effect and discuss the drivers of our results in terms of belief in the legitimacy of the selection procedure and reduced social distance.
\end{abstract}

Mots clés/Key words: Altruism, Democracy, Earned role, Efficiency, Elitism, Entitlement effect, Inequality, Majority-rule, Meritocracy, Social preferences.

Codes JEL/JEL codes: C91, D63, D64

\footnotetext{
* We thank Friedel Bolle, Paolo Crosetto, David Hugh-Jones, Maria Pavlova and Björn Vollan for their comments.

${ }^{\dagger}$ Chair of Microeconomics, Faculty of Economic Sciences, Georg-August-Universität, Göttingen, Germany. email: alexia.gaudeul@wiwi.uni-goettingen.de

$¥$ Chair of Microeconomics, Faculty of Economic Sciences, Georg-August-Universität, Göttingen, Germany, and CIRANO, Montréal, Canada. email: claudia.keser@uni-goettingen.de
} 


\section{Introduction}

Democratic decision making affects the choice of policies, but also the behavior of those who live and rule in a democratic regime. Democracy has an instrumental effect through the choice of policy, but also a behavioral effect. In the context of cooperation in public good production, Bó et al. (2010) showed that a policy that aims at inducing cooperative behavior is more effective when it is chosen democratically than when it is imposed externally; this is what they call the endogeneity premium. ${ }^{1}$ Grossman \& Baldassarri (2012); Gatiso \& Vollan (2017); Vollan et al. (2013) show that this effect of democracy on cooperation has some ecological validity. ${ }^{2}$

We further this research by extending it to the case of indirect democracy. Direct democracy, as investigated by Bó et al. (2010), is such that all those concerned take part in the choice of policies. This is however only one way in which democracy may be implemented. Indeed, the majority of countries that are called "democratic" are indirect, representative democracies. In this case, participants in a democracy choose decision makers, after which decision makers make decisions on behalf of others. Unlike Bó et al. (2010), we therefore do not consider the effect of democratic choice of policy in the context of cooperation, but rather the impact of democratically selecting decision makers in the context of investment decisions. We are interested in whether decisions that are made by democratically elected leaders result in higher wealth generation and more equal distribution of wealth. We measure outcomes in terms of the payoff of the ruled constituents, in terms of the level of inequality in payoffs between rulers and ruled, and in terms of total welfare, including the welfare of the ruler. In other words, we determine whether democratic leaders are more altruistic, whether they are more concerned about inequality, and whether they attain more efficient outcomes.

A large literature discusses the merits of democratic systems (John Stuart Mill, 1861; Amartya Sen, 1999) and compares them with "other forms (of government) that have been tried from time to time" (Churchill, 1947). Ideally, democracy is a way to select good leaders and easily get rid of bad ones (Berganza, 2000). However, voters can be too apathetic and irrational to hold officials sufficiently accountable (Caplan, 2007). Ideally also, democracy is a way to make sure that officials represent the will of the people. However, this will of the people can go against the interests of the State (Plato, 2017, Book VIII), penalize minorities (Mill, 1859) and reduce social welfare by "leveling-down" in the name of equality (Parfit, 1997).

We therefore focus in this paper on democracy as a delegation system. However, rather than considering the instrumental effect of elections, such as how they select better leaders or punish bad ones, we consider the behavioral effect of democracy on the rulers. We investigate whether the way decision makers are selected influences their social preferences, as measured by how altruistic, fair and efficient they are. ${ }^{3}$ We thus contrast the effect of different selection procedures on the priorities of decision makers. ${ }^{4}$

Our analysis will focus on whether democratic systems reduce or increase the feelings of entitlement among leaders. Any system of selection into the role of decider can lead deciders to develop a sense of entitlement—an "inflated self"-that justifies inequality (Piff, 2014). For example, recent

\footnotetext{
${ }^{1}$ Specifically, when participants in a repeated prisoners' dilemma decide democratically to impose a fine on defectors, then cooperation by those who voted for that policy is more likely than if that policy was imposed externally.

${ }^{2}$ Gallier et al. (2017) provide an interesting examination of the negative consequences when participants in a democracy cannot agree on a policy.

${ }^{3}$ In this text, we say that someone is fair if they make equal allocations across individuals. We recognize however the wide range of interpretations of fairness, including those taking account of need and merit.

${ }^{4}$ In that sense, our research differs from those investigating procedural preferences (Frey et al., 2004). We do not consider whether people prefer democratic procedures, but rather whether they behave differently under such procedures. The two may however be linked, and we will indeed consider whether those who express attachment to democracy are particularly likely to be affected by it.
} 
evidence shows that educational elites have distributional preferences that are more egoistic, but also more efficiency-oriented than others (Fisman et al., 2015). Although democratic leaders are often drawn from the same elites (Besley \& Reynal-Querol, 2011), they may differ because their source of entitlement is different. They derive legitimacy from the votes they gained. The issue is that they may consider that they gained those votes through their own campaigning skill, or because voters recognized their superior qualification for the job. They may also consider they won a competition, thus entitling them to behaving less than fairly (Schurr \& Ritov, 2016).

In order to control and isolate those possible entitlement effects of democracy, we run four treatments by combining two dimensions by which leaders may be selected: whether they are elected, and whether there is a way to assess their ability. If deciders are chosen at random, then the system is demarchic (Zeitoun et al., 2014). If they are selected by ability, then the system is meritocratic. If they are selected by a vote, then the system is democratic. Within democratic systems, we make the difference between the case where ability is known to the voters, and the case where it is unknown. In our experiment, we will provide voters with a signal of the ability of the candidates in one treatment, and contrast it with a treatment where voters do not have such a signal. This will allow us to control for the possible entitlement effect of seeing one's ability recognized by others as a legitimate reason to be elected. We will therefore be able to say under what conditions the democratic process moderates or exacerbates feelings of entitlement.

\section{Literature}

The behavioral effect of democratic processes on the rulers has been explored empirically by exploiting differences in the way leaders are selected across countries and context. Leaders of more democratic countries have been shown to be as egoistic, wasteful, self-serving, prone to bribery, embezzlement or nepotism than others (Rock, 2009). However, at lower administrative levels, democracy has been shown to make leaders more responsive to the needs of their community (Grossman, 2014) and more pro-social (Landmann \& Vollan, 2017). There are however two main issues with the empirical approach. One of them is that it is difficult to compare leaders of groups that elect their leaders with leaders of groups whose leaders gain their position in other ways. Indeed, the differences between those leaders may be the result of differences between those groups. A second issue is that democracy and meritocracy do not exist in their "pure" forms in reality. Voters take account of the abilities of candidates, and non-democratic leaders try to get the adhesion of those they lead. Elements of democracy and meritocracy therefore cohabit, which makes it difficult to clearly distinguish their effect.

This is why the experimental approach, with the ability to control all aspects of the context, can be useful in furthering the comparative study of democracy and other governance systems. Previous experiments on democracy have looked at the instrumental effect of democratic selection of democratic leaders. Those have two aspects: how voters sanction bad leaders, and how they select good ones (Berganza, 2000). Voters have been shown to use retrospective voting rules (Woon, 2012), so that a concern with re-election gives an incentive for leaders to behave well (Dasgupta, 2009). Voters have also been shown to select more pro-social leaders (Hamman et al., 2011). Other experiments underline another behavioral effect of democracy, which is due to aversion for lying: candidates dislike breaking their promises once they have been elected (Geng et al., 2011; Corazzini et al., 2014; Walkowitz \& Weiss, 2017). In our experiment, we do not let participants make promises, and we do not let them either build a reputation. This should therefore limit the effect of the voting procedure on the decisions made, since neither feelings of guilt or the wish to be re-elected can moderate egoism. Our experiment thereby focuses on the contextual effect of demo- 
cratic selection. There is only one election, which is made before decisions are made, candidates cannot make promises, and voters cannot judge how pro-social a candidate might be. This allows us to isolate the behavioral effect of the democratic context on the decisions of democratic leaders.

A closely related experiment finds no effect of the democratic selection of decision makers (Kamei, 2017). In that experiment, voters decided what class of participants, ranked by their performance in an effort task, would make decisions for them. Whether their decision was then implemented happened at random. Our experiment differs from Kamei (2017) in a number of ways. First, the slider task that is used in Kamei (2017) is painstaking and does not involve much skill (Gill \& Prowse, 2011). It may therefore not generate much pride in the outcome. Our selection task involves calculations of increasing difficulty, and may thus generate a higher level of identification with the outcome and stronger belief in the validity of selecting according to its result. ${ }^{5}$ Second, the outcome of voting is implemented only with some probability in Kamei (2017). This may have made participants feel that their choice, or the democratic process, was not important. In our experiment, we only ask participants to vote if that vote is going to be implemented. Finally, the only information that participants in Kamei (2017) were provided with was the ranking of other participants in the slider task, while we offer voters other, more personal criteria by which to select leaders. Overall, we think that our design gives more legitimacy to the use of the democratic process and a higher degree of adherence to its outcome. This makes our experiment more ecologically valid. ${ }^{6}$

\section{Experimental design}

In our experiment, we consider a setting that is of interest to both business and politics: the decision how much to invest in a project given its characteristics. The project may be wasteful (negative rate of return), neutral (zero rate of return) or efficient (positive rate of return). Benefits of the project may accrue mainly to the decision maker or to others. The money to be invested may belong to the decision-maker, or it may be the property of others-in which case whatever is not invested goes back to them. The range of investment types this corresponds to therefore spans a whole range of situations-from the decision of a local politician who invests tax money into projects that are mainly of benefit to others, to the decision of a business owner who invests his own money in a project that benefits him mainly.

Decision makers in our experiment were presented with a series of such investment decisions. In each case, how much the decision maker invested determined the total amount of social surplus generated and the share of this surplus going to the recipient. Decision makers thus had to decide how to balance their own payoff, inequality, and efficiency.

Participants in our experiment were assigned randomly to different leadership selection procedures. The way decision makers were selected depended on the treatment. The decision-maker could be selected at random ("Random" treatment). S/he could be selected based on his/her ranking of performance in a preliminary ability test ("Rank" treatment). Finally, s/he could be selected based on the number of votes gained in an election. We ran two variations of the election procedure. In the "Vote" treatment, voters obtained information only on the personality of the candidates. In the "Vote+Rank" treatment, voters also obtained information about the performance of the candidates in the preliminary ability test. All those procedures have in common that they resulted in

\footnotetext{
${ }^{5}$ In Kamei (2017), an issue is that participants may differ in their view of past performance: are high scorers tired and thus unlikely to perform well again, or are they of higher ability? In fact, voting results show that high, middle and low scorers are equally likely to be elected. This shows that voters differed in their view of past performances.

${ }^{6}$ Another experiment, with electoral promises and a low number of observations (12 per treatment), indicates that entitlement effects are not affected by voting (Weiss \& Wolff, 2013).
} 
participants being divided into two groups, decision makers and recipient.

\subsection{Timeline of the experiment}

Participants in our experiment proceeded along the following steps:

1. Personality: Participants had to choose five adjectives describing themselves, out of a list of five mutually exclusive alternatives. For each alternative, they chose the adjective that corresponded them best. The list of adjectives correspond to a reduced form version of the big five personality test (Rammstedt \& John, 2007, see Appendix A). In a later stage, we provided information about the adjectives chosen by candidates to voters (in the voting treatments). For consistency, we also provided this information, but without the possibility to vote, in other treatments. Participants did not know, at the time when they selected adjectives describing themselves, that this would be shown (anonymously) to other participants. There was therefore no strategic aspect to the choice of adjectives. We did not expect personality to affect the choice of whom to vote for, and we did not expect personality to affect investment decisions. Rather, we collected and then disclosed information about personality to differentiate individuals, to give voters a reason to choose one or the other person to vote for, and thus to give some credibility to the voting process. The advantage of this method is that elected individuals maintained their anonymity in the experiment. They did not have to disclose their name, gender, picture and other socioeconomic information as in standard elections. Unlike in Geng et al. (2011); Weiss \& Wolff (2013); Walkowitz \& Weiss (2017), we did not let participants make promises or choose adjectives connoting their intentions. Indeed, we are only interested in the impact of differences in selection procedures on the preferences of deciders. We are not investigating if deciders feel constrained by their promises and the intentions they express.

2. Preliminary questions: Participants were asked about their preferred mode of group decision and the importance for them of living in a democracy. They were also asked for their views on the fairness of establishing a link between salary and performance in a job (Appendix B). We will use answers to those questions to control for procedural preferences and views on fairness. Indeed, those can impact the effect of our treatments on the investment decisions of deciders.

3. Math test: Participants took a test of mathematical ability (addition, subtraction, multiplication and division). The test was in three stages of eight questions each, increasing in difficulty and under time pressure. This was preceded by a question about the importance for them of performing well in a test of mathematical ability. This was followed by two questions about how they felt they had performed (Appendix C). Participants did not know, at the time they took this test, how it would be used in the rest of the experiment. We use results in this test to select participants for decider roles in the "Rank" treatment. We also reveal those results to voters in the "Vote+Rank" treatment. We tested mathematical skills because voters could plausibly see those as relevant when choosing who to vote for, since they were told that decision makers would make investment decisions. Furthermore, leaders selected on the basis of their result in that test could also plausibly derive legitimacy from that test, in the sense that it could make sense to them that we, the experimenters, would choose them based on that criterion. However, at the investment decision stage, we provided deciders with tables that showed the distributional consequences of their investment decisions. Making invest- 
ment decisions did not therefore really require mathematical skills; participants were merely making allocation decisions as in Andreoni \& Miller (2002).

4. List and vote: Participants were then assigned into groups of six. They were shown a table presenting the adjectives chosen by each member of their group (Appendix D). In treatments "Rank" and "Vote+Rank", they also saw the rank of their peers in the mathematical test. Rank was binary: in the top half in the group or in the bottom half.

In the vote treatments, participants also had to indicate whom they would like to be elected to take decisions on their behalf (more detail is provided in section 2.2). Each group member could vote for only one person, excluding themselves. Voters did not know exactly what kind of task would be performed by decision makers; they were simply told that "the persons in your group who were most frequently chosen will make investment decisions for other people in your group."

5. Pairing: Participants were then assigned to be a decision-maker or a recipient. This was done according to rules that depended on the treatment (randomly, by rank, by vote, see section 2.2). Half of the participants in a group were decision makers and half were recipient. Decision-maker were paired with a recipient in their own group. They were asked to make investment decision on their own behalf and that of the recipient, as explained below. Pairs were always such that one member had performed in the top half in the mathematical test while the other had performed in the bottom half. Only participants in the "Rank" and "Vote+Rank" treatments were told of their performance in the test (top or bottom).

6. Investment decisions: We designed a new task to translate investment decisions into allocation preferences. Decision makers were given 100 experimental currency units ("ECU”) to invest for each of a series of 16 investment decisions. They could invest in multiples of 20 ECU: Investment $I \in\{0,20,40,60,80,100\}$. The decision to invest $I$ resulted in the following amounts (in ECU) for the decision-maker ("me") and for the recipient ("you"):

$$
\begin{aligned}
m e & =k \cdot(100-I)+s \cdot m \cdot I \\
\text { you } & =(1-k) \cdot(100-I)+(1-s) \cdot m \cdot I
\end{aligned}
$$

$(m, s, k)$ are the parameters of the investment decision. $m \in\{0.5,1,1.5,2\}$ is the multiplier. $s \in\{40 \%, 60 \%\}$ is the share of the return on the investment that goes to the decision maker. $k \in\{0,1\}$ indicates whether the money that was not invested goes to the decision-maker $(k=1)$ or to the recipient $(k=0)$. In total therefore, there were offered $4 \times 2 \times 2=16$ investment situations spanning all combinations of $(m, s, k)$. Appendix $\mathrm{E}$ shows how investment decisions were presented to participants. We represent graphically the outcome of decisions in terms of allocation to the self and to the other in Appendix F.

7. Payment: Once all decisions were made, participants drew a number between 1 and 16 from a deck of card. This deck was presented to them individually by the experimenter. The number drawn determined which of their decision, in chronological order, would be paid. ${ }^{7}$ They then were told how much they would receive as a result of their investment decision, as well as how much their recipient would receive. Recipients were informed as well.

8. Questionnaire: Participants filled a questionnaire with some questions on how they felt about the experiment. We asked them their views about inequality, effort and competition (from the World Value Survey). We also collected some socioeconomic variables (Appendix H).

\footnotetext{
${ }^{7}$ We varied the chronological order of decisions systematically across participants.
} 


\subsection{Treatments}

We ran four treatments in this experiment, as shown in Table 1. Participants were fully informed of the rules of selection as decision maker in their own treatment.

Table 1: Treatments

\begin{tabular}{|c|}
\hline Treatment "Random" \\
Math test \\
Adjective elicitation \\
No voting \\
Selection at random \\
\hline
\end{tabular}

Vote $\Downarrow$

\begin{tabular}{|c|}
\hline Treatment "Vote" \\
Math test \\
Adjective elicitation \\
Voting based on adjectives \\
Selection based on votes \\
\hline
\end{tabular}

\begin{tabular}{|c|}
\hline Treatment "Rank" \\
Math test \\
Adjective elicitation \\
No voting \\
Selection based on math test \\
\hline
\end{tabular}

Vote $\Downarrow$

\section{Treatment "Vote+Rank"}

Math test

Rank

$\Longrightarrow$
Adjective elicitation

Voting based on math test + adjectives

Selection based on votes

In treatment "Random", decision makers were selected at random. In each group, after seeing adjectives chosen by each member of their group (Appendix D), three participants were told they had been randomly chosen to be a decision makers. The three others were told they were recipient. Each of the three decision makers was anonymously paired with a different recipient in their group, on behalf of whom they made their decisions. The treatment "Random" is designed to test the behavior of decision makers selected under a demarchic system.

In treatment "Vote", as in all treatments, participants saw adjectives chosen by each member of their group (including themselves). They had to select a person other than themselves whom they would like to make decisions on their behalf in a following stage involving investment decisions. The three participants with the most votes in their group were advised of this result and told they were decision makers. The other three were told they were recipients. The treatment "Vote" is designed to test the behavior of decision makers selected under a democratic system.

In treatment "Rank", the three group-members with the highest number of correct answers, within their group, in the preliminary mathematical test were advised of their rank (top half), and assigned to be decision makers. The treatment "Rank" is designed to test the behavior of decision makers selected under a meritocratic system.

In treatment "Vote+Rank", participants not only saw adjectives chosen by each member of their group (including themselves), but also the rank of each group member in the preliminary mathematical test. Namely, participants were told whether a participant's performance was among the three best (above median) or the three worst (below median) in their group. The three members with the most votes in their group were advised of this and told they were decision makers. The other three were told they were recipient. The treatment "Vote+Rank" is designed to test a democratic system where ability can also be used as factor in selecting leaders. Voters are then free to reproduce selection by ability, as in the "Rank" treatment. 


\subsection{Organization of the experiment}

The experiment was run in November 2016 at the Laboratory for Experiments In Economics ("Leine") in Göttingen (Germany). The pool of participant was managed using ORSEE (Greiner, 2004). All participants were requested to read an online consent form and agree with its terms (by clicking) before registering to take part in an experiment. Participants were guaranteed the anonymity of the data generated during the experiment.

The experiment was programmed using z-Tree (Fischbacher, 2007). 258 participants took part. There were 13 sessions of 12 to 24 participants. $^{8}$ Participants were assigned to groups of six at random. Each group in a session was faced with a different treatment. Participants were paid a fixed fee of 4 euros for turning up to the experiment, and a variable fee depending on the payoff achieved in the experiment. 1 ECU gained translated in 0.10 euros paid. Payoff was on average 10.32 euros and ranged between 4 euros and 16 euros. Participants were 24 years old on average, $47 \%$ were men, $92 \%$ were German citizens, $93 \%$ were students, and $48 \%$ studied economics at the university. The sessions lasted an average of 75 minutes.

The order of investment decisions was systematically randomized across participants and between treatments. Only one decision was paid, selected at random and independently across participants, using a transparently random procedure (draw of card from a pack of numbered cards). Payments was made in cash, individually and confidentially at the end of the experiment. Participants made decisions using a computer interface, and were physically and visually isolated from others into separate stalls. Any communication between participants was forbidden and participants remained anonymous for the whole experiment.

\subsection{Predictions}

We derive four testable hypotheses from an analysis of the role of entitlement and of the democratic process in our experiment. Our first hypothesis is a manipulation check: we verify that participants who performed well in the preliminary mathematical task allocate more money to themselves on average. This hypothesis is supported by the literature on earned roles and earned endowment, whereby participants who earn the money to be distributed or earn the role of decision-maker feel entitled to a larger share of the surplus generated (Hoffman et al., 1994; Oxoby \& Spraggon, 2008; Barr et al., 2015; Dasgupta, 2011). In our experiment, participants were told of their result in the mathematical test only in the "Rank" and "Vote+Rank" treatments. However, we found a high correlation between participants' own perception of their performance and their results. Participants were therefore conscious of their rank, to some extent, in all treatments. We therefore expect that we will find a significant difference in all treatments between amounts allocated to self and amount allocated to the recipient by decision-maker of different ranks. Because we gave explicit feedback on rank in the "Rank" and "Vote+Rank" treatments, we expect that this effect will be particularly pronounced in those treatments. We expect the effect to be particularly strong in the "Rank" treatment because the rank was explicitly made a criterion for selection as decider in that treatment.

Hypothesis 1. [Earned role] Decision makers who performed in the top half in the preliminary mathematical task will allocate a higher share of the surplus to themselves on average. This effect will be particularly pronounced in the "Rank" treatment.

Our second hypothesis is the "democratic norm" hypothesis. We expect that democratic selection changes the context of decisions to the political sphere, in which "individuals behave more fairly

\footnotetext{
${ }^{8} 6$ sessions with 24 participants, 5 sessions with 18 participants, 2 sessions with 12 participants.
} 
than in the market place" (Eichenberger \& Oberholzer-Gee, 1998). Participants who were voted to be decision makers will allocate less money to themselves on average and will make decisions that are more efficient in terms of social surplus generated, on average. Democratic selection supports social norms, which "in distributive struggles, moderate the inclination of human beings to behave like 'gangsters'." (Eichenberger \& Oberholzer-Gee, 1998). Similarly, Grimalda et al. (2008) state that "institutions' allowing more participation in the process of collective choice lead to more 'socially responsible' behavior in the players" and Hamman et al. (2011) state that "democratic delegation helps groups overcome the free-rider problem and generally leads to outcomes that are often both efficient and equitable."

Hypothesis 2. [Democratic norm] Decision makers in treatments "Vote" and "Vote+Rank" will allocate a lower share of the surplus to themselves on average.

Going against this hypothesis, Geng et al. (2011) state that "social approval as conveyed by a vote does not suffice to induce pro-social choices by elected candidates" and that "being elected on the basis of one's personality induces a stronger sense of entitlement [compared to being randomly chosen], leading to less welfare-oriented behavior." It could therefore be that participants will perceive their democratic selection as decision makers as entitling them to a higher share of the surplus, in particular if vote was made on the basis of both personality and performance in the mathematical test (as in the "Vote+Rank" treatment). In that case, a participant who both performed highly in the math test and got voted in may feel even more entitled to a high share of the surplus than a participant that was selected by the experimenter to make decisions on behalf of others based on their performance in the mathematical test. Indeed, s/he now derives his/her legitimacy not from the experimenter but rather from other participants in the experiment. Two sources of entitlement could thus combine in a negative way and negate the role of democratic norms to moderate selfishness. We therefore make the following hypothesis, which we call the "earned democratic role" hypothesis to underline how it relates to how we think that the effect of earned role and democracy will combine:

Hypothesis 3. [Earned democratic role] Top-ranked decision makers in the "Vote+Rank" treatment will allocate a higher share of the surplus to themselves on average than top-ranked decision makers in the "Vote" treatment and decision makers in the "Rank" treatment.

Finally, we consider a "(lack of) legitimacy hypothesis", which affects decisions in the "random" treatment. According to work by Hoffman \& Spitzer (1985); Zeitoun et al. (2014), it could be that participants who were allocated to the role of decider at random will have less of a feeling of entitlement, because random allocation of role prevents participants from considering their role as being earned, that is, giving them the right to unequal payoff divisions. Since every participant had half a chance to be selected as decision maker in the "Random treatment", then an equal split of the surplus may seem to be the only fair allocation. Confirming the above considerations, Mertins et al. (2013) state that "resistance (to unequal sharing) increases with the subjectively perceived unfairness of the selection procedure for the proposer's role", and Frey \& Bohnet (1995) show that "fair" procedures—selecting deciders at random—promote equal sharing. We therefore hypothesize that:

Hypothesis 4. [(Lack of) Legitimacy] Decision makers in the "Random" treatment will allocate the surplus more equally than decision makers in other treatments. 


\section{Results}

We start our presentation of the results with aggregate statistics on the level of investment, welfare generated and shares of surplus allocated to the decision-maker and to the recipient. Table 2 shows the distribution of deciders by treatment, as well as how many deciders were ranked in the top half of the mathematical test in each treatment. We collected 27 and 33 observations for treatments "Random" and "Vote", where the distinction between top and bottom performer was expected not to matter since participants were not appraised of their result, while we collected 27 and 33 observations of top performing deciders in treatments "Rank" and "Vote+Rank". We notice that most elected participants in the "Vote+Rank" treatment were top performers as well (33 out of 42). As wanted, voters considered the mathematical test as a plausible criterion for selection; they took good performance as a sign that the person would make good decisions in the investment task.

Table 2: Deciders by rank and treatment

\begin{tabular}{cccccc}
\hline \multicolumn{5}{c}{ Treatment } \\
\hline Rank & Random & Vote & Rank & Vote+Rank & Total \\
Bottom & 14 & 13 & 0 & 9 & 36 \\
Top & 13 & 20 & 27 & 33 & 93 \\
\hline Total & 27 & 33 & 27 & 42 & 129 \\
\hline
\end{tabular}

We illustrate and interpret the empirical distribution of decisions made in Appendix G.

\subsection{Treatment effects on outcomes}

In terms of share taken by the decider, we find that top ranked participants took a higher share of the surplus than lower ranked individuals, on average (62.3\% vs. 59.8\%), and this effect is present across all treatments except "Vote" where the shares taken were equal (Table 3). We also find that decision makers in treatments with voting took a lower share of the surplus than others $(61.1 \%$ in the "Vote" treatment and 59.6\% in the "Vote+Rank" treatment, vs. $63.4 \%$ in the "Random" treatment and $63.7 \%$ in the "Rank" treatment). This holds in particular for top ranked decision makers, while the effect is not present for bottom ranked decision makers.

In terms of surplus generated, we consider statistics excluding data where the multiplier is 1 , since in that case total surplus is always 100 . We find that deciders in treatments with voting generated higher social welfare overall, and this is again driven by the behavior of top ranked decision makers (Table 3). 
Table 3: Share of the surplus and social surplus generated, by treatment and rank (mean, sd, N).

\begin{tabular}{|c|c|c|c|c|c|c|c|}
\hline \multicolumn{5}{|c|}{ Share to the decider } & \multicolumn{3}{|c|}{ Surplus generated } \\
\hline \multicolumn{4}{|c|}{ Rank } & \multicolumn{4}{|c|}{ Rank } \\
\hline Treatment & bottom & top & Total & Treatment & bottom & top & Total \\
\hline \multirow[t]{3}{*}{ Random } & $60.6 \%$ & $66.3 \%$ & $63.4 \%$ & Random & 130.2 & 124.9 & 127.7 \\
\hline & $7.7 \%$ & $7.3 \%$ & $7.9 \%$ & & 4.8 & 7.6 & 6.8 \\
\hline & 14 & 13 & 27 & & 14 & 13 & 27 \\
\hline \multirow[t]{3}{*}{ Vote } & $61.1 \%$ & $61.1 \%$ & $61.1 \%$ & Vote & 129.7 & 131.0 & 130.5 \\
\hline & $6.2 \%$ & $9.6 \%$ & $8.3 \%$ & & 8.4 & 10.3 & 9.5 \\
\hline & 13 & 20 & 33 & & 13 & 20 & 33 \\
\hline \multirow[t]{3}{*}{ Rank } & . & $63.7 \%$ & $63.7 \%$ & Rank & . & 129.5 & 129.5 \\
\hline & & $7.7 \%$ & $7.7 \%$ & & & 7.4 & 7.4 \\
\hline & 0 & 27 & 27 & & 0 & 27 & 27 \\
\hline \multirow[t]{3}{*}{ Vote+Rank } & $56.7 \%$ & $60.4 \%$ & $59.6 \%$ & Vote+Rank & 129.4 & 132.5 & 131.8 \\
\hline & $2.8 \%$ & $8.2 \%$ & $7.5 \%$ & & 6.2 & 6.6 & 6.6 \\
\hline & 9 & 33 & 42 & & 9 & 33 & 42 \\
\hline \multirow[t]{3}{*}{ Total } & $59.8 \%$ & $62.3 \%$ & $61.6 \%$ & Total & 129.8 & 130.2 & 130.1 \\
\hline & $6.3 \%$ & $8.4 \%$ & $7.9 \%$ & & 6.4 & 8.1 & 7.7 \\
\hline & 36 & 93 & 129 & & 36 & 93 & 129 \\
\hline
\end{tabular}

We test the significance of those results by performing non-parametric tests on the difference between mean individual shares taken by the decider and mean individual total surplus generated. A two-sample Wilcoxon rank-sum (Mann-Whitney) test shows that the share taken by the decider is on average lower in vote treatments (two-sided test, $z=2.166, p=0.030$ ), while the total generated is only marginally higher $(z=-1.838, p=0.066)$. This confirms the results of a t-test of the equality of means ( $t=2.340, p=0.021$ for the share of the total, $t=-1.977, p=0.050$ for the total). A two-sample Kolmogorov-Smirnov test for equality of distribution functions gives out a p-value, corrected for ties, of 0.065 for the share of the total, and of 0.256 for the total. A Kruskal-Wallis equality-ofpopulations rank test gives out a chi-squared of $4.687(p=0.030)$ for the share of the total, and a chi-squared of $3.370(p=0.066)$ for the total.

We further test the significance of those results by running random-effects interval-data regression that take into account the panel structure of our data and interval censoring-participants were limited to multiples of $20 \mathrm{ECU}$ in their choice of investment and could not invest less than 0 ECU and more than 100 ECU (Table 4). For comparison, we also provide results of randomeffect panel regressions, without taking into account censoring and interval elicitation. All our regressions are boot-strapped with replacement at the individual level (100 iterations). 
Table 4: Panel regressions on the total welfare and share allocated to self.

\begin{tabular}{lcccc}
\hline & \multicolumn{2}{c}{$(1)$} & $(2)$ & \multicolumn{2}{c}{$(3)$} & \multicolumn{2}{c}{$(4)$} \\
& \multicolumn{2}{c}{ with interval censoring } & \multicolumn{2}{c}{ without interval censoring } \\
& $m e+$ you & me $/$ me + you & me + you & me $/$ me + you \\
top ranked & 7.9581 & $0.1118 * *$ & -0.0821 & $0.0309+$ \\
& $(1.43)$ & $(2.69)$ & $(-0.06)$ & $(1.84)$ \\
Treatment with vote & $9.4485 *$ & $-0.1051 *$ & $2.5833 *$ & $-0.0305 *$ \\
& $(2.12)$ & $(-2.28)$ & $(2.09)$ & $(-2.37)$ \\
Treatment with rank & 3.1731 & -0.0482 & 1.5582 & -0.0174 \\
& $(0.53)$ & $(-0.98)$ & $(0.98)$ & $(-1.16)$ \\
Constant & $146.8238 * * *$ & $0.8142 * * *$ & $127.8466 * * *$ & $0.6212 * * *$ \\
& $(31.76)$ & $(16.10)$ & $(99.77)$ & $(41.24)$ \\
\hline$N$ observations & 1548 & 2064 & 1548 & 2064 \\
$N$ individuals & 129 & 129 & 129 & 129 \\
ll & -2551 & -2617 & & 3 \\
df & 3 & 3 & 3 & 15.47 \\
$\chi^{2}$ & 11.05 & 15.68 & 8.12 & 0.0015 \\
$\mathrm{p}$ & 0.0115 & 0.0013 & 0.0436 & \\
\hline
\end{tabular}

$t$ statistics in parentheses, bootstrapped, 100 iterations.

$+p<0.10, * p<0.05, * * p<0.01, * * * p<0.001$

We find that differences in the share allocated to self between treatments with rank and without are not significant $(-5 \%, p>5 \%$, taking into account interval censoring, $-2 \%, p>5 \%$, without taking into account interval censoring). Differences between treatment with vote and without are however significant $(-11 \%, p=0.023$, with interval censoring, $-3 \%, p=0.018$, without interval censoring). Differences in the total surplus generated are not significant however $(+9.4 \mathrm{ECU}$ with censoring, $p=0.034,+2.6 \mathrm{ECU}, p=0.037$, without censoring). Differences in allocations made by top and bottom ranked individuals are significant $(+11 \%, p=0.007,+3 \%, p=0.066){ }^{9}$

Those tests therefore confirm that the share taken by the decider is robustly significantly lower in vote treatments, while the total generated is higher, but less robustly significantly so.

Those overall differences hold on average, but it is also interesting to look at differences across different types of investments as this gives us insights on the drivers of our result. Indeed, concern with equality and with efficiency impact decisions in different ways depending on whether the multiplier is less than one, where more equality leads to lower welfare, and when the multiplier is more than one, where more equality promotes welfare. A decision-maker who is driven by efficiency would have to sacrifice equality when equality reduces welfare, and would promote equality and at the same time efficiency when equality increases welfare.

We find that treatment differences in terms of the fairness of allocations are robust across tasks (Appendix I). We see in Table 6 that the mean share of the surplus taken by an elected decider is lower in 13 of the 16 investment situations, equal in one situation and higher by a minimal margin in two situations. In terms of surplus generated, Table 7 shows that surplus generated by an elected decider is higher in 8 situations out of 12 (we do not consider situations where the multiplier is one, whereby surplus is always 100), lower in three situations, and equal in one situation. In particular, we see that when $m=0.5$ and $k=0$, the elected deciders generated more surplus, which indicates they were more comfortable receiving little if that was the efficient choice. However, surplus generated by elected deciders was lower when $m=0.5$ and $k=1$, which may

\footnotetext{
${ }^{9}$ Results do not depend on whether we control for the rank of the individual. Without controlling for rank, $-11 \%$ is allocated to self in vote treatments if we take account of censoring, $p=0.016,-3 \%$ when comparing means, $p=0.018 .+8.9$ ECU is generated in vote treatments if we take account of censoring, $p=0.120,+2.6$ ECU when comparing means, $p=0.031$.
} 
have been driven by not being comfortable receiving much more than the recipient, even if that was the efficient choice. This explains why overall surplus generated by elected deciders was not significantly higher than surplus generated by non-elected deciders: democratic leaders are more reluctant to sacrifice equality for efficiency if that benefits them.

In summary, results support hypothesis 1 (earned role), whereby participants feel an entitlement to a higher share of the surplus if their performance in the preliminary mathematical task was better than the median in their group. However, this effect does not depend on whether the experimenter (in the rank treatment) confirmed, by their assignment of the role of decider to the top ranked individuals, that rank in the test was a good reason to assign the role of decider to a person. Our results also support hypothesis 2 (democratic norm), as participants allocated a lower share of the surplus to themselves if they were voted to make decisions. However, the effect of being elected on efficiency was not significant. We find no support for hypothesis 3 (earned democratic role), as participants who were voted to make decisions and were higher ranked in the mathematical task did not make decisions that were more unfair than those of other higher ranked individuals. Finally, we find no support for hypothesis 4 (legitimacy), as lacking legitimacy did not lead decision makers in the "Random" treatment to make fairer decisions.

We discuss our interpretation and test for alternative explanations of our results in section 4 . Before doing so, however, we want to determine if allocations made by elected leaders were fairer (more equal) because they were more inequality averse, or whether this is due to the combination of more altruistic and efficient decisions. Indeed, looking at the share given and the total surplus generated does not allow us to see what drove decisions: for example, altruism can be efficiencyreducing, so that lower efficiency could be due to higher altruism or vice-versa. We therefore further our analysis by reproducing the method used in Engelmann \& Strobel (2004) to investigate the drivers of investment decisions of our participants.

\subsection{Treatment effects on motivations}

We estimate a conditional logit model whereby we characterize each choice of an investment level $j \in[0,20,40,60,80,100]$ in every investment decision scenarios $k$ by their payoff for the self $S E L F_{k j}=$ $m e_{k j}$, their level of efficiency $E F F_{k j}=m e_{k j}+y_{0 u_{j j}}$ and their level of inequality $I N E Q_{k j}=$ $\left|m e_{k j}-y_{0 u_{j}}\right|$. Individual $i$ 's utility from choosing investment level $j$ in scenario $k$ is given by

$$
U_{i j k}=\alpha S E L F_{k j}+\beta E F F_{k j}+\gamma I N E Q_{k j}+\epsilon_{i j k}
$$

with $\epsilon_{i j k}$ i.i.d with type I extreme value distribution.

In each scenario $k$, the individual chooses the allocation with the highest utility, that is, we observe

$$
\begin{aligned}
& y_{i j k}=1 \text { if } j=\arg \max _{j}\left(U_{i j k}\right) \\
& y_{i j k}=0 \text { else }
\end{aligned}
$$

Again, all our regressions are boot-strapped with replacement at the individual level (100 iterations). We report our results in Table 5. 
Table 5: Alternative specific logit regressions

\begin{tabular}{|c|c|c|c|c|}
\hline dependent variable & $\begin{array}{c}(1) \\
\text { investment }\end{array}$ & $\begin{array}{c}(2) \\
\text { investment }\end{array}$ & $\begin{array}{c}(3) \\
\text { investment }\end{array}$ & $\begin{array}{c}(4) \\
\text { investment }\end{array}$ \\
\hline me & $\begin{array}{l}0.0675 * * * \\
(11.05)\end{array}$ & $\begin{array}{l}0.0824 * * * \\
(7.43)\end{array}$ & $\begin{array}{l}0.0654 * * * \\
(8.36)\end{array}$ & $\begin{array}{l}0.0800 * * * \\
(6.80)\end{array}$ \\
\hline INEQ & $\begin{array}{l}-0.0154 * * * \\
(-5.93)\end{array}$ & $\begin{array}{l}-0.0176 * * * \\
(-3.91)\end{array}$ & $\begin{array}{l}-0.0112 * * * \\
(-3.49)\end{array}$ & $\begin{array}{l}-0.0136 * \\
(-2.55)\end{array}$ \\
\hline $\mathrm{EFF}$ & $\begin{array}{l}0.0044 \\
(1.55)\end{array}$ & $\begin{array}{l}-0.0042 \\
(-0.94)\end{array}$ & $\begin{array}{l}0.0028 \\
(0.66)\end{array}$ & $\begin{array}{l}-0.0055 \\
(-1.11)\end{array}$ \\
\hline me $\times$ vote & & $\begin{array}{l}-0.0237+ \\
(-1.75)\end{array}$ & & $\begin{array}{l}-0.0241+ \\
(-1.78)\end{array}$ \\
\hline INEQ $\times$ vote & & $\begin{array}{l}0.0029 \\
(0.51)\end{array}$ & & $\begin{array}{l}0.0033 \\
(0.62)\end{array}$ \\
\hline $\mathrm{EFF} \times$ vote & & $\begin{array}{l}0.0142 * \\
(2.36)\end{array}$ & & $\begin{array}{l}0.0141 * \\
(2.38)\end{array}$ \\
\hline me $\times$ rank & & & $\begin{array}{l}0.0045 \\
(0.38)\end{array}$ & $\begin{array}{l}0.0058 \\
(0.48)\end{array}$ \\
\hline INEQ $\times$ rank & & & $\begin{array}{l}-0.0082 \\
(-1.62)\end{array}$ & $\begin{array}{l}-0.0084 \\
(-1.59)\end{array}$ \\
\hline $\mathrm{EFF} \times$ rank & & & $\begin{array}{l}0.0031 \\
(0.55)\end{array}$ & $\begin{array}{l}0.0024 \\
(0.40)\end{array}$ \\
\hline $\mathrm{N}$ alternatives & 12384 & 12384 & 12384 & 12384 \\
\hline $\mathrm{N}$ decisions & 2064 & 2064 & 2064 & 2064 \\
\hline $\mathrm{N}$ id & 129 & 129 & 129 & 129 \\
\hline ll & -2689 & -2670 & -2681 & -2662 \\
\hline $\mathrm{df}$ & 3 & 6 & 6 & 9 \\
\hline$\chi^{2}$ & $171 * * *$ & $173 * * *$ & $188 * * *$ & $195 * * *$ \\
\hline
\end{tabular}

$t$ statistics in parentheses, bootstrapped, 100 iterations.

$+p<0.10,{ }^{*} p<0.05,{ }^{* *} p<0.01,{ }^{* * *} p<0.001$

The first column of Table 5 shows that participants in the "Random" treatment are motivated to increase payoff to the self (significantly positive coefficient on $m e$ ) and are averse to inequality (significantly negative coefficient on INEQ), but are not significantly sensitive to efficiency concerns (insignificantly positive coefficient on EFF).

The second column of Table 5 show that participants in Vote treatments were less driven by payoff to the self (negative coefficient on me $\times$ vote, $p<10 \%$, i.e. they are more altruistic) and significantly more driven by efficiency (positive coefficient on $\mathrm{EFF} \times$ vote, $p<5 \%$ ). Vote treatments do not affect how much they care about inequality. This shows that efficiency was significantly more important for democratically elected decision makers in the vote treatments.

The third column of Table 5 shows that the effect of being in Rank treatments was not significant and the fourth column in Table 5 shows that results hold also when considering both Rank and Vote in our regressions.

\subsection{How motivations translate into outcomes}

Our analysis shows that decision makers in vote treatments were more driven by efficiency considerations. This can appear surprising since total welfare generated was not significantly higher in vote treatments, while allocations made were fairer (more equal). This can be explained by the 
role of altruism.

- When $k=0$ and $m>1$, then both efficiency and inequality aversion encourage deciders to invest everything; since most do so, treatment differences are very small.

- When $k=0$ and $m<1$, then altruism and efficiency lead the decider to invest less in vote treatments, which generates more inequality.

- When $k=1$ and $m>1$, then altruism and efficiency both motivate the elected decider to invest more, which reduces inequality.

- Finally, when $k=1$ and $m<1$, then altruism and efficiency conflict. The coefficient on $m e \times$ vote is higher than the coefficient on $E F F \times$ vote, Table 5 . This indicates that the effect of a vote on the altruism of decision makers may be stronger than its effect on their orientation towards efficiency. Altruism therefore wins out over efficiency considerations when the two factors conflict. Deciders in the vote treatments thus invest more in this specific case, which reduces inequality.

The result of this complex interplay of motivations is that, when averaged over our specific set of investment tasks, elected leaders did not generate more wealth but made more equal distributions.

\section{Robustness, mediation analysis and selection effect}

\subsection{Pool of participants and experimental conditions}

We perform boot-strapping at the individual level for all our regressions, which shows that our results are robust to changes in the composition of the pool of participants within treatments. We also test our results by including control variables for differences in experimental conditions across treatments. Regressions shown in Table 8 of Appendix I include socioeconomic variables (column 1 and 4), ${ }^{10}$ dummies for the day of the week (63\% of the participants took part on Thursdays) and the time of day (morning or afternoon) (columns 2 and 5), and dummies for the adjectives chosen to describe themselves and score for the mathematical task (columns 3 and 6). We find that our results are robust to those controls.

\subsection{Mediation analysis}

We consider in this part different causal chains that could lead to our treatment effect. Our hypothesis is that differences in procedures influence the decisions of decision makers (behavioral effect), rather than changing the type of persons selected to make decisions (selection effect).

We first offer evidence supporting a behavioral effect: the democratic procedure was important to our participants (1), those who were assigned to use the democratic procedure were more satisfied with their own procedure than other participants (2) and participants in treatments using the democratic procedure felt closer to other participants in the experiment (3). We present evidence against a selection effect in the next section.

\footnotetext{
${ }^{10}$ We include gender, age, whether the participant lives alone, whether they have money concerns, how they evaluate their financial situation compared to others and whether they study economics at the university. More than $90 \%$ of the participants lived in Göttingen, were German, were students and did not study economics before university. We therefore do not include those variables.
} 


\section{1) Importance of the democratic procedure.}

Most participants in our experiment believed in the importance of living in a democracy. $74 \%$ of the 258 participants said that living in a democracy was very important to them vs. $22 \%$ who said it was important and only $4 \%$ who said either that it was not very important or not important at all (preliminary question 2, Appendix B). Participants also believed in making group decisions together: $72 \%$ of the participants preferred reaching a decision by consensus, $22 \%$ preferred to vote, $4 \%$ preferred to leave the decision to a more experience person and $2 \%$ preferred to let one person to take the responsibility (preliminary question 1 ).

\section{2) Approval for the democratic procedure.}

Decision makers were much more likely to state that they approved the selection procedure in the vote treatments (question 2, questionnaire before learning payoffs, Appendix H). $64 \%$ of decision makers approved the selection procedure in the "Vote" and in the "Vote+Rank" treatments, compared with $41 \%$ in the "Random" treatment and only $30 \%$ in the "Rank" treatment. ${ }^{11}$ This finding is consistent with the high rate of belief in the importance of living in a democracy in our sample.

\section{3) Feeling of closeness}

Participants in the vote treatments also exhibited higher feelings of having something in common with other participants (question 8, after learning payoffs, Appendix H). 64\% said they felt so in the "Vote" treatment, 52\% in the "Vote+Rank" treatment, 37\% in the "Random" treatment and only 30\% in the "Rank" treatment. ${ }^{12}$ This could be the result of engaging more with the tables describing other group participants when having to choose whom to vote for than when the information is merely presented for consideration (in the "Rank" and "Random" treatments). Selection by rank in the mathematical test may have promoted a feeling that distinctions between high and low performer matter, and thus lowered feelings of commonality with others.

Those results indicates that a possible driver of our results is a feeling, for decision makers in vote treatment, that they were selected in an appropriate, legitimate and satisfying way to make decisions on behalf of others. Furthermore, the voting procedure gave them more of a feeling that they had something in common with other participants. Results are consistent with the idea that our treatment effect is due to a change in context, whereby the democratic procedure generated higher feelings of satisfaction, legitimacy and belonging.

\subsection{Evidence against a selection effect}

Information provided to voters in the vote treatment was meant to provide credible criteria for the choice of whom to vote for, while not changing the composition of the pool of deciders. Our aim was thereby to avoid a selection effect. However, we still need to check that our results are not impacted by a selection effect, that is, that the pool of deciders was the same across treatments in terms of the psychological characteristics selected for, and/or that characteristics selected for did not impact allocations made. Indeed, an alternative explanation for our results could be that voters selected people with psychological characteristics that are more conducive to good decisions for the recipient. Personality has been shown to influence decisions in a range of economic games (Müller

\footnotetext{
${ }^{11}$ This is so even though only $30 \%$ of participants in the vote treatments judged that they had sufficient information to make a choice who to vote for.

${ }^{12}$ This result cannot be driven by higher objective similarity between participants across sessions. Indeed, participants in each session were divided into groups, each groups participating in a different treatment.
} 
\& Schwieren, 2017). The issue then is whether voters are able to select for those personality characteristics that will lead to higher payoffs for themselves. We find that the democratic procedure did not lead to important differences in the make-up of the pool of deciders. Voters preferred individuals who were "gründlich" (thorough) and "entspannt" (relaxed) (likelihood to be elected, logit regressions), as well as higher ranked individuals in the math test for the Vote+Rank treatment. However, the only variable that affected sharing of the surplus was one that was not taken into account by voters: individuals who were "vertrauend" (trustful) gave more to the recipient. Further invalidating the selection hypothesis, voters did not select against top performers in the math test, quite on the contrary, even though higher ranked participants distributed less to the recipients in the Vote+Rank treatment. We ran the regressions also including how close, in terms of psychological characteristics, one was from other group member, in order to test whether participants voted for participants who were like them. However, we find that this did not significantly influence vote.

Another way in which voting could have affected the composition of the pool of decision makers, at least in the Vote+Rank treatment, is that voters favored decision makers who performed well in the mathematical test (33 of the 42 deciders in the Vote+Rank treatment were top ranked). Top ranked participants were more likely to be male (58\% of men were in the top half vs. $43 \%$ of women) and to have studied economics (57\% of economists were in the top half vs. $44 \%$ of noneconomists). However, running our regressions of Table 4 with those controls (cf. Table 4.1), we find that neither gender or being an economist affected the sharing of surplus, although we do find that males generated higher social surplus. Treatment differences remain significant and of the same magnitude as without those controls.

\section{Discussion and open questions}

Our experiment raises a few questions for future research. A first one is with regards to framing. Our experiment was framed as an investment decision, which raises the question of whether our finding could be generalized to other type of sharing decisions. Our choice of frame favors an economic rather than a political approach to the problem, which could have reduced the impact of employing a democratic procedure for selecting a leader. Our treatment effects are therefore probably in the lower range of what could be expected in situations that are more typically handled by politicians.

Another issue is that our participants were university students with a high rate of adherence to democratic norms. It would be interesting to consider other types of populations that may not have been raised with such deference to democracy. Elitist institutions indeed often encourage their alumni to use their skills in the service of others: "noblesse oblige", that is, status entails responsibility. Assigning decision-making to the best performers in a context where individuals believe that being part of the elite is associated with duties to others may also encourage more equal sharing of the surplus and more focus on efficiency.

Related to this question is that of the drivers of the effect of the democratic process on the deciders. We proposed several ways in which the effect may be mediated, such as a change in context from the economic to the political, reduced social distance between participants, increased feeling of responsibility for others, or wish to reciprocate the favor of being elected.

In terms of social distance, participants in voting and non-voting treatments were all provided with the same information about other group members (see Appendix D), but social distance (feeling that was is similar to others in the session) was lower in treatment with voting. This may be because voting generated higher engagement with the characteristics and differences between 
other participants-because of the need to make a choice among them. Having to vote may thus have encouraged more attention to such information, and thus higher levels of association and identification with others in the group.

Beyond reduced social distance, another way to interpret our results is that deciders felt more responsible for others if others trusted them to make decisions on their behalf, by voting for them. Participants who were chosen by others to make economic decisions on their behalf would want to meet the expectations of their voters. This effect can be likened to how trust is reciprocated in (Berg et al., 1995), or to how, in labor market experiments, workers reciprocate higher wages with higher effort (Fehr et al., 1998). Slonim \& Garbarino (2007) show that being able to choose one's partner in a trust or a dictator game also increases trust and altruism. The effect of trust conferred by other participants in the "Vote" and "Vote+Rank" treatment would be greater than the effect of trust conferred by the experimenter in the "Rank" treatment, either because we did not make it explicit that we, the experimenters, trusted the decision-maker to make decisions, or simply because we, the experimenters, were not a party in the decisions so that our trust could not be reciprocated.

In our experiment, voters were not able to select the individual who would take the investment decision on their behalf in our experiment-participants voted for someone, but this did not know guarantee that the person they voted for would make the decision for them. Also, the decisionmaker did not know if the person they took decisions for voted for them. Testing the selection and reciprocation hypothesis would require matching deciders with voters who either did or did not vote for them, and seeing if that makes a difference. Another possibility would be to get decision makers voted in by a group of individuals that is different from the one they will make decisions for. Such variations on our design would allow to distinguish different effects of democratic procedures-higher legitimacy $v s$. more feelings of responsibility $v s$. lower social distance.

\section{Conclusion}

In our experiment, we asked individuals to make decisions that affected their own welfare and that of another person. We varied the procedure to select decision makers. In one treatment, deciders were selected at random. In another, they were selected based on their performance in a test. In two other treatments, they were selected based on a vote by their peers. We found that elected decision makers were more driven by efficiency considerations than others, but also less egoistic. While they were not more concerned by inequality in payoffs, their decisions resulted in more equal distributions of payoffs.

We tested the robustness of this democratic effect by generating an "elite" in our experiment. Those were the participants who performed best in a test of mathematical ability. This "elite" had a sense of entitlement; it took a higher share of the surplus than others. However, this entitlement effect was reduced when this "elite" was democratically selected by their peers to make decisions, rather than exogenously assigned to make decisions. Voting was thus an effective check on egoistic behavior by the "elite".

Our analysis indicates that most participants perceived democratic selection of decision makers as being fair. Other procedures did not generate such adherence. The voting procedure also generated lower social distance with others. This may be why it generated more altruism. However, it is not clear why democratic leaders also showed more concern for efficiency.

In this respect, we remark that the voting procedure in our experiment did not only give equal value to the vote of each individual but also entitled everyone to vote. Equal vote may induce 
valuing others as equals, while universal vote may induce as sense of a "community of citizens", whose overall welfare must be promoted. It may be that a universal right to vote and an equal weighting of votes have different impacts on decisions. It would be interesting to vary those two dimensions independently, by giving different weights to the vote of different individuals, and manipulating who is allowed to vote, or who is eligible to be elected. Exploring those dimensions of the democratic procedures would allow a better identification of the sources of the effect of democratic procedures on the choice of policies by democratic leaders.

\section{References}

Amartya Sen (1999). Development as Freedom. New York: Knopf. (ref. p. 2).

Andreoni, J., \& Miller, J. (2002). Giving according to GARP: An experimental test of the consistency of preferences for altruism. Econometrica, 70(2), 737-753. (ref. p. 6, 26).

Bardsley, N. (2008). Dictator game giving: Altruism or artefact? Experimental Economics, 11(2), 122-133. (ref. p. 26).

Barr, A., Burns, J., Miller, L., \& Shaw, I. (2015). Economic status and acknowledgement of earned entitlement. Journal of Economic Behavior \& Organization, 118, 55-68. (ref. p. 8).

Berg, J., Dickhaut, J., \& McCabe, K. (1995). Trust, reciprocity, and social history. Games and Economic Behavior, 10(1), 122-142. (ref. p. 18).

Berganza, J. C. (2000). Two roles for elections: Disciplining the incumbent and selecting a competent candidate. Public Choice, 105(1-2), 165-194. (ref. p. 2, 3).

Besley, T., \& Reynal-Querol, M. (2011). Do democracies select more educated leaders? American Political Science Review, 105(03), 552-566. (ref. p. 3).

Bó, P. D., Foster, A., \& Putterman, L. (2010). Institutions and behavior: Experimental evidence on the effects of democracy. American Economic Review, 100(5), 2205-2229. (ref. p. 2).

Caplan, B. D. (2007). The Myth of the Rational Voter: Why Democracies Choose Bad Policies. Princeton, NJ: Princeton University Press. (ref. p. 2).

Churchill, W. (1947). Debate at the House of Commons. Parliament Bill (Hansard, 11 November 1947). http://hansard.millbanksystems.com/commons/1947/nov/11/parliament-bill\#column_ 207. (ref. p. 2).

Corazzini, L., Kube, S., Maréchal, M. A., \& Nicolò, A. (2014). Elections and deceptions: An experimental study on the behavioral effects of democracy. American Journal of Political Science, 58(3), 579-592. (ref. p. 3).

Dasgupta, S. (2009). The disciplining role of repeated elections: Some experimental evidence. New Zealand Economic Papers, 43(2), 165-190. (ref. p. 3).

Dasgupta, U. (2011). Do procedures matter in fairness allocations? Experimental evidence in mixed gender pairings. SSRN Scholarly Paper ID 1796484, Social Science Research Network, Rochester, NY. (ref. p. 8).

Eichenberger, R., \& Oberholzer-Gee, F. (1998). Rational moralists: The role of fairness in democratic economic politics. Public Choice, 94(1-2), 191-210. (ref. p. 9). 
Engelmann, D., \& Strobel, M. (2004). Inequality aversion, efficiency, and maximin preferences in simple distribution experiments. American Economic Review, 94(4), 857-869. (ref. p. 13).

Fehr, E., Kirchler, E., Weichbold, A., \& Gächter, S. (1998). When social norms overpower competition: Gift exchange in experimental labor markets. Journal of Labor Economics, 16(2), 324-351. (ref. p. 18).

Fischbacher, U. (2007). z-Tree: Zurich toolbox for ready-made economic experiments. Experimental Economics, 10(2), 171-178. (ref. p. 8).

Fisman, R., Jakiela, P., Kariv, S., \& Markovits, D. (2015). The distributional preferences of an elite. Science, 349(6254), aab0096. (ref. p. 3).

Frey, B. S., Benz, M., \& Stutzer, A. (2004). Introducing procedural utility: Not only what, but also how matters. Journal of Institutional and Theoretical Economics JITE, 160(3), 377-401. (ref. p. 2).

Frey, B. S., \& Bohnet, I. (1995). Institutions affect fairness: Experimental investigations. Journal of Institutional and Theoretical Economics (JITE) / Zeitschrift für die gesamte Staatswissenschaft, 151(2), 286-303. (ref. p. 9).

Gallier, C., Kesternich, M., \& Sturm, B. (2017). Voting for burden sharing rules in public goods games. Environmental and Resource Economics, 67(3), 535-557. (ref. p. 2).

Gatiso, T. T., \& Vollan, B. (2017). Democracy and cooperation in commons management: Experimental evidence of representative and direct democracy from community forests in ethiopia. Environment and Development Economics, 22(2), 110-132. (ref. p. 2).

Geng, H., Weiss, A. R., \& Wolff, I. (2011). The limited power of voting to limit power. Journal of Public Economic Theory, 13(5), 695-719. (ref. p. 3, 5, 9).

Gill, D., \& Prowse, V. (2011). A novel computerized real effort task based on sliders. Discussion Paper 5801, IZA. (ref. p. 4).

Greiner, B. (2004). The online recruitment system ORSEE 2.0 - A guide for the organization of experiments in economics. Working Paper Series in Economics 10, Department of Economics, University of Cologne. (ref. p. 8).

Grimalda, G., Kar, A., \& Proto, E. (2008). On the value of participation: Endogenous emergence of social norms in a three-player ultimatum game experiment. International Review of Economics, 55(1), 127-147. (ref. p. 9).

Grossman, G. (2014). Do selection rules affect leader responsiveness? Evidence from rural Uganda. Quarterly Journal of Political Science, 9(1), 1-44. (ref. p. 3).

Grossman, G., \& Baldassarri, D. (2012). The impact of elections on cooperation: Evidence from a lab-in-the-field experiment in Uganda. American Journal of Political Science, 56(4), 964-985. (ref. p. 2).

Hamman, J. R., Weber, R. A., \& Woon, J. (2011). An experimental investigation of electoral delegation and the provision of public goods. American Journal of Political Science, 55(4), 738-752. (ref. p. 3, 9). 
Hoffman, E., McCabe, K., Shachat, K., \& Smith, V. (1994). Preferences, property rights, and anonymity in bargaining games. Games and Economic Behavior, 7(3), 346-380. (ref. p. 8).

Hoffman, E., \& Spitzer, M. L. (1985). Entitlements, rights, and fairness: An experimental examination of subjects' concepts of distributive justice. The Journal of Legal Studies, 14(2), 259-297. (ref. p. 9).

John Stuart Mill (1861). Considerations on Representative Government. Buffalo, NY: Prometheus Books. (ref. p. 2).

Kamei, K. (2017). Collective selection of representatives and the democracy effect. SSRN Scholarly Paper ID 2932094, Social Science Research Network, Rochester, NY. (ref. p. 4).

Landmann, A., \& Vollan, B. (2017). Local leaders and pro-social beliefs: The effect of becoming elected. Working paper, Paris School of Economics and Phillips-University Marburg. (ref. p. 3).

List, J. A. (2007). On the interpretation of giving in dictator games. Journal of Political Economy, 115(3), 482-493. (ref. p. 26).

Mertins, V., Egbert, H., \& Könen, T. (2013). The effects of individual judgments about selection procedures: Results from a power-to-resist game. The Journal of Socio-Economics, 42, 112-120. (ref. p. 9).

Mill, J. S. (1859). On Liberty. London: John W. Parker and Son. (ref. p. 2).

Müller, J., \& Schwieren, C. (2017). Using personality questionnaires in experiments - limits and potentials. MPRA Paper No. 78132. (ref. p. 16).

Oxoby, R. J., \& Spraggon, J. (2008). Mine and yours: Property rights in dictator games. Journal of Economic Behavior \& Organization, 65(3-4), 703-713. (ref. p. 8).

Parfit, D. (1997). Equality and priority. Ratio, 10(3), 202-221. (ref. p. 2, 26).

Piff, P. K. (2014). Wealth and the inflated self: Class, entitlement, and narcissism. Personality and Social Psychology Bulletin, 40(1), 34-43. (ref. p. 2).

Plato (2017). The Republic. Seattle, WA: AmazonClassics. Trans. Benjamin Jowett. (ref. p. 2).

Rammstedt, B., \& John, O. P. (2007). Measuring personality in one minute or less: A 10-item short version of the Big Five Inventory in English and German. Journal of Research in Personality, 41, 203-212. (ref. p. 5, 23).

Rock, M. T. (2009). Corruption and democracy. The Journal of Development Studies, 45(1), 55-75. (ref. p. 3).

Schurr, A., \& Ritov, I. (2016). Winning a competition predicts dishonest behavior. Proceedings of the National Academy of Sciences, 113(7), 1754-1759. (ref. p. 3).

Slonim, R., \& Garbarino, E. (2007). Increases in trust and altruism from partner selection: Experimental evidence. Experimental Economics, 11(2), 134-153. (ref. p. 18).

Vollan, B., Zhou, Y., Landmann, A., Hu, B., \& Herrmann-Pillath, C. (2013). Cooperation under democracy and authoritarian norms. Working Paper 2013-14, Universität Innsbruck. (ref. p. 2). 
Walkowitz, G., \& Weiss, A. (2017). "Read my lips! (but only if I was elected)!" Experimental evidence on the effects of electoral competition on promises, shirking and trust. Journal of Economic Behavior \& Organization, 142, 348-367. (ref. p. 3, 5).

Weiss, A. R., \& Wolff, I. (2013). Does being elected increase subjective entitlements? Evidence from the laboratory. Economics Bulletin, 33(1), 794-796. (ref. p. 4, 5).

Woon, J. (2012). Democratic accountability and retrospective voting: A laboratory experiment. American Journal of Political Science, 56(4), 913-930. (ref. p. 3).

Zeitoun, H., Osterloh, M., \& Frey, B. S. (2014). Learning from Ancient Athens: Demarchy and corporate governance. The Academy of Management Perspectives, 28(1), 1-14. (ref. p. 3, 9). 


\section{Appendices}

\section{Appendix A Personality questionnaire}

Please choose the adjectives that best describes you:

1. Aspect 1. I am more a) reserved (zurückhaltend). b) sociable (gesellig).

2. Aspect 2. I am more a) trusting (vertrauend). b) distant (distanziert).

3. Aspect 3. I am more a) strict (gründlich). b) easy-going (locker).

4. Aspect 4. I am more a) relaxed (entspannt). b) nervous (nervös).

5. Aspect 5. I am more a) imaginative (phantasievoll). b) objective (sachlich).

Note: In parenthesis are the German adjectives as proposed to participants. Questions are adapted from the German version of the 10-item Big Five questionnaire of Rammstedt \& John (2007). Question 1 measures Extraversion, Question 2 measures Agreeableness, Question 3 measures Conscientiousness, Question 4 measures Neuroticism, and Question 5 measures Openness.

\section{Appendix B Preliminary questionnaire}

1. How do you think common decisions should be made? (Please choose only one option)

(a) I prefer to discuss decisions and find a consensus together.

(b) I prefer for a person to take responsibility and make decisions for all.

(c) I prefer to put choices to a vote and choose the majority decision.

(d) I prefer to leave decisions to more experienced others.

2. How important is it for you to live in a country that is governed democratically? 1 . Not important at all. 2. Not very important. 3. Important. 4. Very important.

3. Assume two people perform the same job in the same company. Both have the same qualification, but Person A works more productively than Person B. Is it fair that Person A gets paid more? 1. Yes 2. No

\section{Appendix C Mathematical test}

1. In general, is it important for you to perform well in a mathematical test? 1. Yes 2. No.

2. Please answer these 8 questions. You have a minute for that. You can leave some or all fields free: $88-45,10+30,57-43,9 \times 6,3 \times 7,8+45,65-11,2 \times 5$.

3. Please answer these 8 questions. You have a minute for that. You can leave some or all fields free: $276+177,12 / 4,106-85,18 / 6,4 \times 10,188-64,106+122,8 \times 7$.

4. Please answer these 8 questions. You have a minute for that. You can leave some or all fields free: 70/10, 892-179, 8x8, $363+93,77 / 11,9 \times 5,642-193,265+108$.

5. Did you find the test difficult? 1. Yes 2. No.

6. Do you think you have done well in this test? 1 . Yes 2 . No. 


\section{Appendix D Group list, (vote) and feedback}

We show examples of how information about peers in the group was conveyed to participants in the "List" phase of the experiment:

\section{Treatment "Random"}

You see an anonymous list of the other participants in your group.

\begin{tabular}{|c|c|c|c|c|c|}
\hline Your Group & Aspect 1 & Aspect 2 & Aspect 3 & Aspect 4 & Aspect 5 \\
\hline \hline Group member 1 & gesellig & distanziert & gründlich & nervös & phantasievoll \\
\hline Group member 2 & zurückhaltend & vertrauend & locker & entspannt & sachlich \\
\hline Group member 3 & zurückhaltend & distanziert & locker & nervös & phantasievoll \\
\hline Group member 4 & zurückhaltend & distanziert & gründlich & entspannt & phantasievoll \\
\hline Group member 5 & gesellig & vertrauend & gründlich & nervös & sachlich \\
\hline Yourself & gesellig & distanziert & gründlich & entspannt & phantasievoll \\
\hline
\end{tabular}

\section{Treatment "Vote"}

You see an anonymous list of the other participants in your group. Please select the person whom you would most prefer to make investment decisions for you. Please put a check mark in the rightmost column for this person. Every other member of your group will also choose one person for themselves. In the next part of the experiment, the persons in your group who were most frequently chosen will make investment decisions for other people in your group.

\begin{tabular}{|c|c|c|c|c|c|c|}
\hline Your Group & Aspect 1 & Aspect 2 & Aspect 3 & Aspect 4 & Aspect 5 & Your vote \\
\hline \hline Group member 1 & gesellig & distanziert & gründlich & nervös & phantasievoll & $\square$ \\
\hline Group member 2 & zurückhaltend & vertrauend & locker & entspannt & sachlich & $\square$ \\
\hline Group member 3 & zurückhaltend & distanziert & locker & nervös & phantasievoll & $\square$ \\
\hline Group member 4 & zurückhaltend & distanziert & gründlich & entspannt & phantasievoll & $\square$ \\
\hline Group member 5 & gesellig & vertrauend & gründlich & nervös & sachlich & $\square$ \\
\hline Yourself & gesellig & distanziert & gründlich & entspannt & phantasievoll & \\
\hline
\end{tabular}

\section{Treatment "Rank"}

You see an anonymous list of the other participants in your group and how they have scored in the test compared to the majority of the others in your group.

\begin{tabular}{|c|c|c|c|c|c|c|}
\hline Your Group & Aspect 1 & Aspect 2 & Aspect 3 & Aspect 4 & Aspect 5 & Test result \\
\hline \hline Group member 1 & gesellig & distanziert & gründlich & nervös & phantasievoll & better \\
\hline Group member 2 & zurückhaltend & vertrauend & locker & entspannt & sachlich & better \\
\hline Group member 3 & zurückhaltend & distanziert & locker & nervös & phantasievoll & worse \\
\hline Group member 4 & zurückhaltend & distanziert & gründlich & entspannt & phantasievoll & worse \\
\hline Group member 5 & gesellig & vertrauend & gründlich & nervös & sachlich & better \\
\hline Yourself & gesellig & distanziert & gründlich & entspannt & phantasievoll & \multirow{2}{*}{ worse } \\
\hline
\end{tabular}

\section{Treatment "Vote+Rank"}

You see an anonymous list of the other participants in your group and how they have scored in the test compared to the majority of the others in your group. Please select the person whom you would 
most prefer to make investment decisions for you. Please put a check mark in the rightmost column for this person. Every other member of your group will also choose one person for themselves. In the next part of the experiment, the persons in your group who were most frequently chosen will make investment decisions for other people in your group.

\begin{tabular}{|c|c|c|c|c|c|c|c|}
\hline Your Group & Aspect 1 & Aspect 2 & Aspect 3 & Aspect 4 & Aspect 5 & Test result & Your vote \\
\hline \hline Group member 1 & gesellig & distanziert & gründlich & nervös & phantasievoll & better & $\square$ \\
\hline Group member 2 & zurückhaltend & vertrauend & locker & entspannt & sachlich & better & $\square$ \\
\hline Group member 3 & zurückhaltend & distanziert & locker & nervös & phantasievoll & worse & $\square$ \\
\hline Group member 4 & zurückhaltend & distanziert & gründlich & entspannt & phantasievoll & worse & $\square$ \\
\hline Group member 5 & gesellig & vertrauend & gründlich & nervös & sachlich & better & $\square$ \\
\hline Yourself & gesellig & distanziert & gründlich & entspannt & phantasievoll & worse & \\
\hline
\end{tabular}

\section{Appendix E Investment decisions: Experimental represen- tation}

You receive ECU 100. You can invest part of those 100 ECU.

You may invest either ECU 0, ECU 20, ECU 40, ECU 60, ECU 80 or ECU 100.

Your investment is multiplied by 2.0 .

You receive $40 \%$ of the outcome of this investment.

The other person receives the remaining $60 \%$.

You keep the money you do not invest.

How much do you want to invest?

\begin{tabular}{|l|l|l|l|l|l|}
\hline 0 & 20 & 40 & 60 & 80 & 100 \\
\hline
\end{tabular}

Support for your decision: The following table shows how many ECUs you and the other person will receive as a function of your investment decision.

\begin{tabular}{|c|c|c|c|c|c|c|}
\hline Your investment & 0 & 20 & 40 & 60 & 80 & 100 \\
\hline \hline Your payoff & 100 & 96 & 92 & 88 & 84 & 80 \\
\hline Payoff of the other person & 0 & 24 & 48 & 72 & 96 & 120 \\
\hline
\end{tabular}

\section{Appendix F Investment decisions: Graphical representation and interpretation}

Figure 1 represents the allocations in the (me, you) space. Each line corresponds to a different investment situation. Each point on the line corresponds to a different level of investment $I$. If $k=1$, then $m e+\frac{1-s m}{(1-s) m}$ you $=100$ s.t. $m e \in[\min (100,100 s m), \max (100,100 s m)]$. If $k=0$, then $\frac{1-(1-s) m}{s m} m e+y o u=100$ s.t. $m e \in[0,100 s m]$. For illustration, we indicate the point reached when $I=80$ in the case with $m=2, k=0, s=40 \%$ (top left). We also show on the graph the equality line $(m e=y o u)$, and, as an example, the iso-efficiency line where the sum me + you is equal to 150 ECU. 
$k=0, s=40 \%$

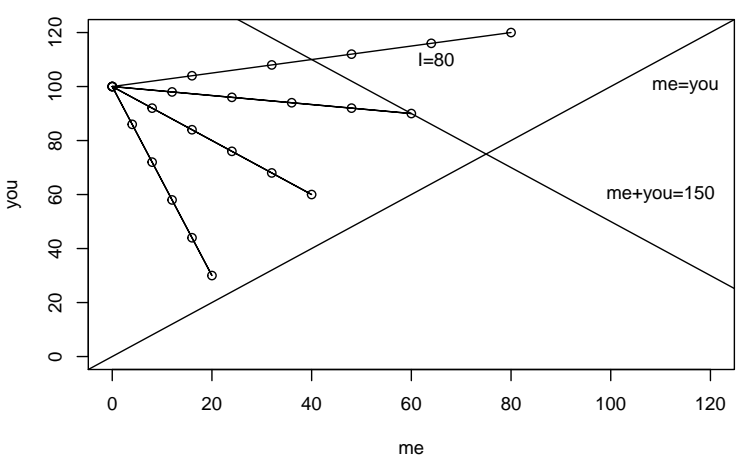

$k=0, s=60 \%$

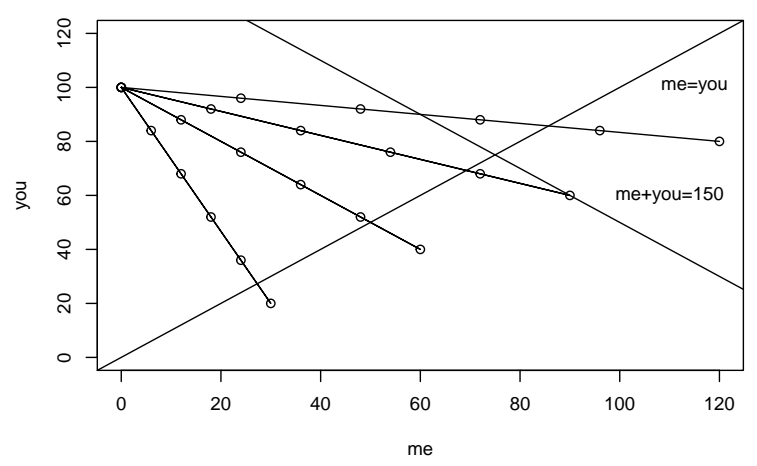

$k=1, s=40 \%$

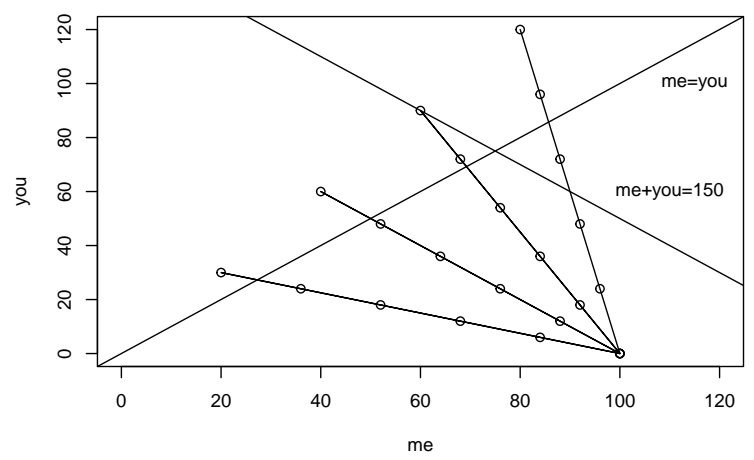

$k=1, s=60 \%$

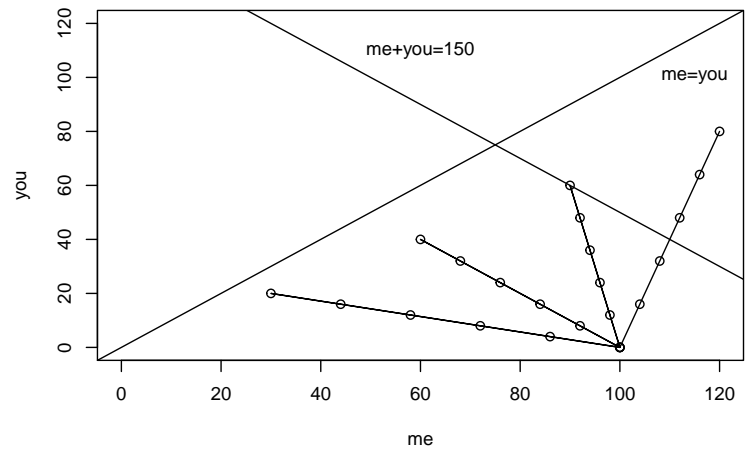

Figure 1: Menus of allocations by values of the multiplier $m$, share $s$, and money kept $k$.

Parameters $(m, s, k)$ can be interpreted as follows:

- $m=0.5$ is a situation in which investment destroys wealth, $m=1$ is a situation where the investment only changes the distribution of wealth, and $m=1.5$ or $m=2$ are situations where investment generates higher wealth. A purely efficiency oriented decision maker maximizes $U(m e, y o u)=y o u+m e$. S/he invests everything as long as $m>1$, invests nothing if $m<1$, and is indifferent when $m=1$.

- $s$ indicates the share of the surplus that goes to the decision maker if s/he invests everything. A purely egalitarian decision maker maximizes Leontief preferences $U(m e, y o u)=$ $\min \{m e, y o u\}$. S/he invests everything if $s=40 \%$ but may invest less than $100 \mathrm{ECU}$ if $s=60 \%$, as this can result in an allocation that is closer to his/her $50 \%$ ideal.

- Finally, $k$ indicates the "default" allocation of wealth. This is what happens if the decisionmaker invests nothing. By varying $k$, we vary the "owner" of the money to be invested. This was shown to matter in the dictator game: the dictator takes less from a recipient endowed with $100 \mathrm{ECU}$ than is consistent with what s/he gives when s/he is endowed with $100 \mathrm{ECU}$ (Bardsley, 2008; List, 2007).

We note that if $s \times m>1$, which happens if $s=60 \%$ and $m=2$, then there is no conflict between increasing allocation to myself and to the other. As in Andreoni \& Miller (2002), we can then see if some decision-maker are ready to earn less in order for the recipient to earn less. This can be the result of jealousy or spite. It can also be justified under egalitarian preferences, whereby the decision-maker may "level-down" rather than maximize total welfare, if maximizing total welfare generates too much inequality (Parfit, 1997). 


\section{Appendix G Investment decisions: Empirical distribution}

Figure 2 illustrates the overall distribution of decisions made in the experiment by all deciders. In the figure, the size of a marker indicates the number $N$ of participants, out of the 129 deciders, who chose a given allocation for a given investment decision (there are 16 decisions to make, each with 6 alternatives).

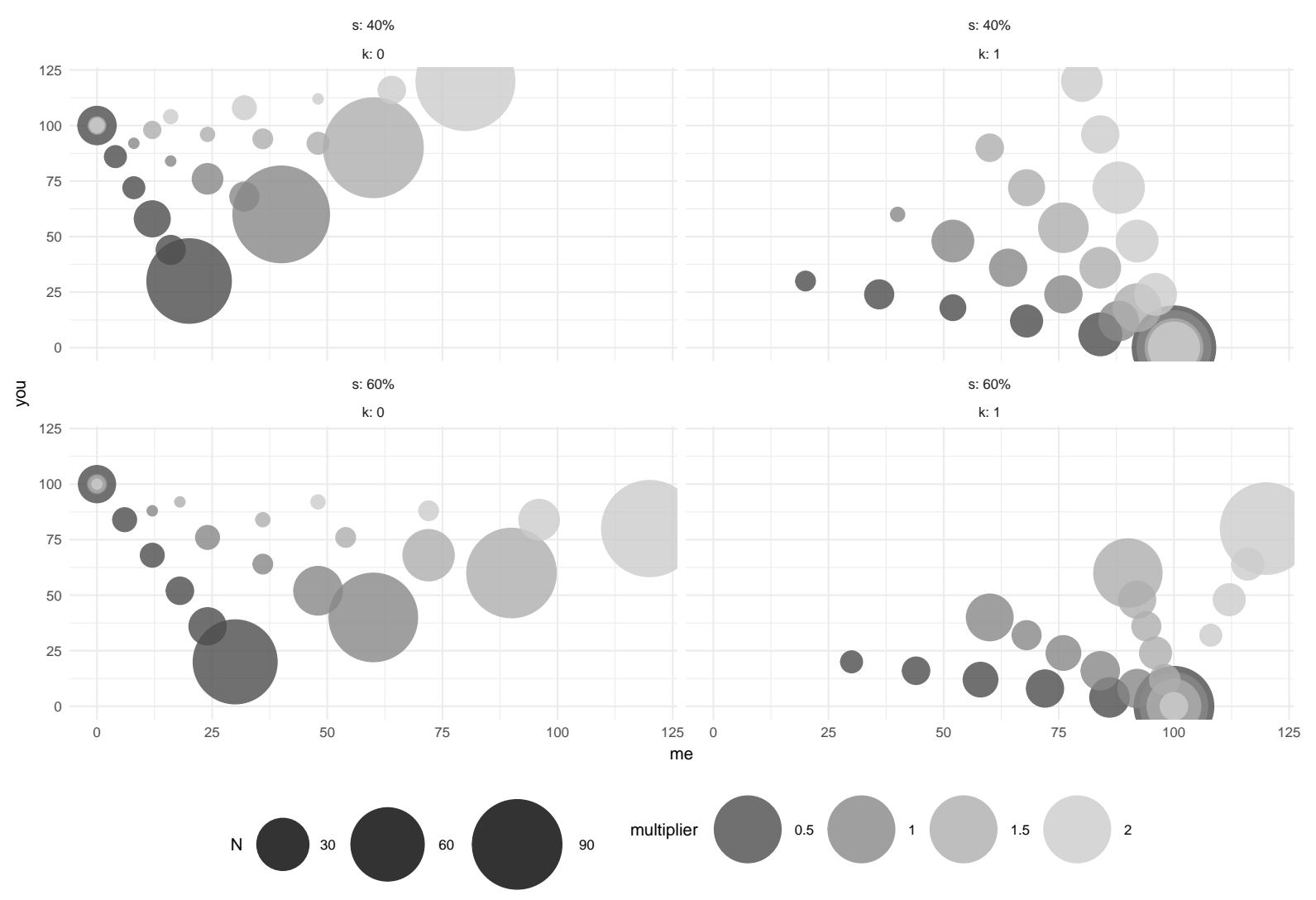

Figure 2: Distribution of allocations chosen, by type of investment, in ECU

We find that if the decider does not "own" the money $(k=0)$, and receives only $40 \%$ of the investment returns ( $s=40 \%$ ), then a large majority of deciders invest everything ( $I=100$, points to the right), with the exception of the case where $m=0.5$ in which a minority invests nothing. This can be linked to efficiency preferences. The case with $k=0$ and $s=60 \%$ is similar, except that a number of participants invest $I=80$ rather than the maximum, which can be linked to egalitarian preferences and aversion to advantageous inequality. In the case $k=1$ and $s=40 \%$, very few participants invested the maximum $(I=100)$, which indicates aversion to disadvantageous inequality, and many invested nothing, which indicates egoistic preferences - except in the case where $m=0.5$ where this decision can be justified by efficiency preferences. The situation is similar in the case where $k=1$ and $s=60 \%$ except that a large number of participants invested everything when $m=2$, which suggests that most participants do not have spiteful preferences. 


\section{Appendix H Questionnaire}

\section{Before learning payoffs:}

1. Do you think that the information provided to you was sufficient to decide whom you would most like to make investment decisions for you? (In treatments "Vote" and "Vote + Rank").

2. Do you think that it was a good thing to choose the person who made the investment decisions for himself and another person,

(a) purely randomly? (In treatment "Random")

(b) by a vote of all participants? (In treatments "Vote" and "Vote + Rank")

(c) by their performance in the mathematical test? (In treatment "Rank")

\section{After learning payoffs:}

1. What do you think the experiment was about?

2. Please explain how you made your decisions how to invest.

3. Was it hard for you to understand what you had to do in this experiment?

4. Did you have any difficulties during the experiment?

(a) If yes, please describe your difficulties.

5. How many experiments did you already take part in the past (approximately)? (1. I have never participated in an experiment before. 2. 1-5 3. More than 5)

6. Do you know one or more of the other people who participated in the experiment today?

7. Do you think you have much in common with the other participants in today's experiment?

8. In the following questions, if you agree fully with the first opinion, please choose 1; if you agree fully with the second opinion, please choose 4 . You can use the values in between to indicate intermediate levels of agreement.

(a) "Income differences should be reduced." vs. "We need a larger income differential to generate incentives for individual efforts."

(b) "Competition is good, it makes people work hard and develop new ideas." vs. "Competition is harmful, it brings out the worst in people."

(c) "In the long run, hard work pays off." vs. "Hard work does not generally bring success it is more a question of chance and connections."

(d) "People can only become rich at the expense of their fellow human beings." vs. "Wealth can grow so there is enough for everyone"

9. Finally, we would like to have some statistical data about you.

(a) How old are you? Please type your age.

(b) What is your gender?

(c) What is your living situation? 1. I live with my parents and / or other family members. 2. I live alone. 3. I live in a residence with others. 4. I live with my partner and / or children. 
(d) Do you live in the district of Göttingen?

(e) Do you have German citizenship?

(f) Are you worried about covering your cost of living in the next six months?

(g) Do you think you are financially better than other people in your age group?

(h) Are you currently enrolled in a study program?

(i) Have you studied or are you currently studying economics?

i. At a university or university of applied sciences?

ii. In school (for the university / university of applied sciences)?

\section{Appendix I Additional figures and tables}

Table 6: Share to the decider, by type of investment, over treatments with vote and without. In bold is the lower number across treatments with vote and without.

\begin{tabular}{|c|c|c|c|c|c|c|c|c|}
\hline \multirow{8}{*}{$\begin{array}{l}\text { no vote }(\mathrm{N}=54) \\
\text { vote }(\mathrm{N}=75)\end{array}$} & \multicolumn{8}{|c|}{$k=0$} \\
\hline & \multicolumn{4}{|c|}{$s=40 \%$} & \multicolumn{4}{|c|}{$s=60 \%$} \\
\hline & $m=0.5$ & $m=1$ & $m=1.5$ & $m=2$ & $m=0.5$ & $m=1$ & $m=1.5$ & $m=2$ \\
\hline & 0.32 & 0.38 & 0.37 & 0.38 & 0.48 & 0.54 & 0.57 & 0.57 \\
\hline & 0.27 & 0.36 & 0.38 & 0.38 & 0.41 & 0.52 & 0.54 & 0.58 \\
\hline & \multicolumn{8}{|c|}{$k=1$} \\
\hline & \multicolumn{4}{|c|}{$s=40 \%$} & \multicolumn{4}{|c|}{$s=60 \%$} \\
\hline & $m=0.5$ & $m=1$ & $m=1.5$ & $m=2$ & $m=0.5$ & $m=1$ & $m=1.5$ & $m=2$ \\
\hline no vote $(\mathrm{N}=54)$ & 0.94 & 0.85 & 0.78 & 0.71 & 0.95 & 0.88 & 0.81 & 0.65 \\
\hline vote $(\mathrm{N}=75)$ & 0.90 & 0.82 & 0.72 & 0.65 & 0.92 & 0.83 & 0.72 & 0.64 \\
\hline
\end{tabular}

Table 7: Surplus generated, by type of investment, over treatments with vote and without. In bold is the higher number across treatments with vote and without.

\begin{tabular}{ccccccc}
\hline & \multicolumn{6}{c}{$k=0$} \\
\cline { 2 - 7 } & \multicolumn{5}{c}{$s=40 \%$} & \multicolumn{4}{c}{$s=60 \%$} \\
\cline { 2 - 7 } no vote $(\mathrm{N}=54)$ & $m=0.5$ & $m=1.5$ & $m=2$ & $m=0.5$ & $m=1.5$ & $m=2$ \\
\cline { 2 - 7 } vote $(\mathrm{N}=75)$ & 59 & 146 & $\mathbf{1 9 3}$ & 58 & $\mathbf{1 4 7}$ & 193 \\
& $\mathbf{6 4}$ & $\mathbf{1 4 7}$ & $\mathbf{1 9 3}$ & $\mathbf{6 4}$ & 144 & $\mathbf{1 9 5}$ \\
& \multicolumn{5}{c}{$k=1$} \\
\cline { 2 - 7 } & $m=0.5$ & $m=1.5$ & $m=2$ & $m=0.5$ & $m=1.5$ & $m=2$ \\
nyyyyyyy no vote $(\mathrm{N}=54)$ & $\mathbf{9 3}$ & 116 & 139 & $\mathbf{9 1}$ & 123 & 186 \\
vote $(\mathrm{N}=75)$ & 89 & $\mathbf{1 2 0}$ & $\mathbf{1 5 0}$ & 88 & $\mathbf{1 3 4}$ & $\mathbf{1 8 7}$ \\
\hline
\end{tabular}


Table 8: Panel regression, total welfare and share kept, with controls.

\begin{tabular}{|c|c|c|c|c|c|c|}
\hline & $\begin{array}{l}(1) \\
\text { total }\end{array}$ & $\begin{array}{l}(2) \\
\text { total }\end{array}$ & $\begin{array}{l}(3) \\
\text { total }\end{array}$ & $\begin{array}{c}\text { (4) } \\
\text { share_total }\end{array}$ & $\begin{array}{c}(5) \\
\text { share_total }\end{array}$ & $\begin{array}{c}(6) \\
\text { share_total }\end{array}$ \\
\hline top ranked & $\begin{array}{l}-0.5984 \\
(-0.38)\end{array}$ & $\begin{array}{l}0.0421 \\
(0.02)\end{array}$ & $\begin{array}{l}-1.9262 \\
(-0.69)\end{array}$ & $\begin{array}{l}0.0268 \\
(1.60)\end{array}$ & $\begin{array}{l}0.0322^{*} \\
(2.27)\end{array}$ & $\begin{array}{l}0.0287 \\
(1.32)\end{array}$ \\
\hline Vote treatments & $\begin{array}{l}2.6126^{+} \\
(1.72)\end{array}$ & $\begin{array}{l}2.9265^{*} \\
(2.37)\end{array}$ & $\begin{array}{l}2.1227 \\
(1.57)\end{array}$ & $\begin{array}{l}-0.0353^{* *} \\
(-2.67)\end{array}$ & $\begin{array}{l}-0.0279^{+} \\
(-1.67)\end{array}$ & $\begin{array}{l}-0.0369^{*} \\
(-2.33)\end{array}$ \\
\hline Rank treatments & $\begin{array}{l}0.9556 \\
(0.56)\end{array}$ & $\begin{array}{l}1.5946 \\
(0.99)\end{array}$ & $\begin{array}{l}1.5136 \\
(0.91)\end{array}$ & $\begin{array}{l}-0.0138 \\
(-1.01)\end{array}$ & $\begin{array}{l}-0.0168 \\
(-1.12)\end{array}$ & $\begin{array}{l}-0.0063 \\
(-0.43)\end{array}$ \\
\hline Constant & $\begin{array}{l}121.7666^{* * *} \\
(44.34)\end{array}$ & $\begin{array}{l}126.2677^{* * *} \\
(71.04)\end{array}$ & $\begin{array}{l}128.1994^{* * *} \\
(36.79)\end{array}$ & $\begin{array}{l}0.6150^{* * *} \\
(15.01)\end{array}$ & $\begin{array}{l}0.6108^{* * *} \\
(26.91)\end{array}$ & $\begin{array}{l}0.6623^{* * *} \\
(16.35)\end{array}$ \\
\hline Controls & Sociodemo & Sessions & Big 5 and math & Sociodemo & Sessions & Big 5 and math \\
\hline $\begin{array}{l} \\
\text { N_case } \\
\text { df } \\
\chi^{2} \\
\mathrm{p}\end{array}$ & $\begin{array}{l}1548 \\
129 \\
10 \\
33.9936 \\
0.0002\end{array}$ & $\begin{array}{l}1548 \\
129 \\
5 \\
9.4447 \\
0.0926\end{array}$ & $\begin{array}{l}1548 \\
129 \\
9 \\
11.9925 \\
0.2137\end{array}$ & $\begin{array}{l}2064 \\
129 \\
10 \\
23.8949 \\
0.0079\end{array}$ & $\begin{array}{l}2064 \\
129 \\
5 \\
16.5332 \\
0.0055\end{array}$ & $\begin{array}{l}2064 \\
129 \\
9 \\
40.3368 \\
0.0000\end{array}$ \\
\hline
\end{tabular}

$t$ statistics in parentheses

${ }^{+} p<0.10,{ }^{*} p<0.05,{ }^{* *} p<0.01,{ }^{* * *} p<0.001$ 